\title{
The Challenge of Building Multilingual Collections in Canadian Public Libraries
}

\section{Juris Dilevko and Keren Dali}

A Web-based survey was conducted to determine the extent to which Canadian public libraries are collecting multilingual materials (foreign languages other than English and French), the methods that they use to select these materials, and whether public librarians are sufficiently prepared to provide their multilingual clientele with an adequate range of materials and services. There is room for improvement with regard to collection development of multilingual materials in Canadian public libraries, as well as in educating staff about keeping multilingual collections current, diverse, and of sufficient interest to potential users to keep such materials circulating. The main constraints preventing public libraries from developing better multilingual collections are addressed, and recommendations for improving the state of multilingual holdings are provided.

Juris Dilevko (dilevko@fis.utoronto.ca) and Keren Dali are at the Faculty of Information Studies at the University of Toronto.

Manuscript submitted July 31, 2002; revised manuscript accepted November 4, 2002.

We would like to thank Moya K. Mason, who provided research assistance and database management services for this project.
Tn 1973, the National Library of Canada (NLC) began a centralized Multilingual 1 Biblioservice (MBS) that offered public libraries books in a wide variety of languages other than English and French-the two official languages of Canada. Some twenty years later, it reduced "the scope of the work of MBS and donat[ed] the collection to public libraries and deposit centers across the country" (NLC 1994, 2). In 1994 NLC published A World of Information: Creating Multicultural Collections and Programs in Canadian Public Libraries (AWI) as a way of "offering advisory service to assist public libraries serving ethnocultural minority communities across Canada" (2). AWI was designed to help "librarians in towns and small cities ... establish continuing contacts with the ethnocultural minority communities that may use your library's multilingual collection" and thus "find the support and information you need to manage a multilingual collection" (2-3). It began from the premise that all Canadian public institutions should "respond to the diverse needs and interests of all community members," and specifically invoked the Multiculturalism Policy of Canada, which "reflects a conviction that, by accepting and promoting cultural diversity, Canadian society will develop a shared sense of Canadian identity that respects the diversity of the country and its people" (3). More specifically, AWI quoted guidelines about multilingual (ML) collections issued by the Canadian Library Association, which state that "minority language communities of 300 or more people in a library system should receive service on a fair and equitable per capita level and that, for communities of fewer than 300 people ... libraries should provide at least several basic reference books and a newspaper or periodical title" (3). In addition, AWI featured sections that 
gave practical advice about the importance of establishing contact with minority communities and the ways in which ML communities can help in developing collections by "advising on subjects of interest, popular authors and publications, ... particular community needs . . . and screening titles for acquisitions" (5-6). It also contained detailed information about ways in which to build staff skills so as to better serve ML patrons. For example, the benefits of holding training sessions about the key role of ML newspapers were described, as well as the advantages of workshops about "recent international publications ... . [so that] staff could become familiar with the names of important fiction and non-fiction writers or titles from, for example, Spain, Greece, the Indian sub-continent and China" (22). Finally, AWI stressed the importance of training staff about crosscultural communication patterns insofar as "cultural awareness can help staff to understand the impact of culture on behaviour" (23). In other words, as summarized in the Guidelines for Multilingual Materials Collection and Development and Library Services prepared by the Multilingual Materials Subcommittee (MMS) of the American Library Association, "access to library materials for ethnic, cultural and linguistic groups should not be seen as 'additional' or 'extra' services, but as an integral part of every library's services" (MMS 1990, sec. 1, par. 3). As Wertheimer observes, "the multilingual part of the library must be an oasis, not a ghetto" (1991, 381-82).

In 2000 NLC instituted a review of its collection policies and procedures "to define requirements to build a more broadly based collection for all Canadians, including collections in heritage languages"- - a review that led to recommendations about further study about the state of ML resources and services (Zielinska 2002, 5). As one component of this further study, NLC surveyed 21 large public libraries in various provinces across Canada, including library systems in Vancouver, Calgary, Edmonton, Winnipeg, Hamilton, Toronto, Thunder Bay, Halifax, and St. John's, about the state of their ML collections and the role of NLC in helping them develop such collections. A central finding of this survey was that "only the largest [libraries] are still able to maintain active resources and services in selected heritage languages and that medium and small libraries have a very difficult time in developing resources and providing services in languages represented by the new immigrants" (Zielinksa 2002, 5). Although there are very impressive ML collections at, for example, the Toronto, Vancouver, Surrey, Richmond, and Calgary library systems, other libraries indicated that they "depend on the old material received from the Multilingual Biblioservice in the mid-1990s, or on gifts from the community" (Multicultural Resources and Services 2002). Three of the 21 surveyed systems indicate that they have "no budget" for multilingual collections and services, and another seven sys- tems characterize their budget using the words "not adequate" $(1,5,6,7,8,10,13)$. When library systems do have money to spend, staff members are concerned about "issues in active collection development," including the need "to identify international publishers," as well as the difficulty in finding staff members "that have knowledge of the recent immigration group language[s]" (56). Many library systems would therefore be amenable to NLC services "provided mainly through the Internet, including provision of online acquisition tools, cooperative cataloguing, access to evaluated Internet resources in heritage languages, [and a] directory of multilingual collections" among others (56). As a step toward the realization of these goals, a position for a Coordinator for Multilingual Resources and Services was funded in late 2001 (56).

One interpretation of the recent energy devoted to ML issues by NLC may be that the phasing out of the Multilingual Biblioservice and its replacement by the AWI program did not lead to satisfactory outcomes for ML collections and ML collection development on a national basis. The NLC may have come to the same conclusion as St. Lifer and Nelson, who found, in the United States context, that both white and minority librarians believe that "library collections are not diversified enough to meet the needs of swelling multicultural populations," to say nothing of the fact that the few existing minority librarians believe that "much of the dialog involving diversity in the profession . . . amounts to lip service and hand-wringing" (1997, 43). As noted previously, one reason for the lack of collection diversity may be that budgetary constraints and staff shortages bring about a situation where developing ML collections is viewed as an "extra" activity that does not have a high priority level, given all the other expenditures that need to be made and low demand. Paradoxically, such a view may inadvertently lead librarians to see their ML collections as ancillary entities that are not central to the mission of their libraries. However, MMS emphasizes that "low demand could be the result of situations where inadequate or no service has been previously provided, or, because of low expectations or unfamiliarity with library services on the part of potential users" (MMS 1990, sec. 2.1.2, par. 3). Thus, it recommends that "it may be necessary in the case of smaller and widely scattered groups, to provide a proportionally higher level [of materials] in order to establish a minimal effective collection" (sec. 2.1.3).

The issue of "smaller and widely scattered groups" is particularly germane to the Canadian situation. As summarized by Krauss, the Canadian federal government and various provincial governments have embarked upon "a new immigration policy designed to attract young, preferably large foreign families to rural Canada" (2002, A1). By "creat[ing] more magnets for immigration everywhere," the 
provinces hope to prevent the death of small, rural communities. For instance, Manitoba instituted a policy in the late 1990s "to attract German-speaking Mennonites, Argentine Jews, Filipinos, and Bosnians" to towns such as Steinbach, which have a historical connection to immigrants from certain regions and countries (A8). In addition, New Brunswick is "looking for affluent students from China and Hong Kong, who local officials hope will coalesce into their own community and perhaps attract their families" and Saskatchewan is "looking to Korea and Ukraine to bring experienced farmhands to its hog barns" (A8).

To be sure, as noted by Krauss (2002), $81 \%$ of immigrants settle in the metropolitan areas of Toronto, Vancouver, and Montreal, yet, in light of concerted efforts to attract immigrants to rural areas, public libraries in all parts of Canada may be faced with increased user demand for ML collections and services. The NLC survey described here, referenced as Multicultural Resources and Services (2002), provides invaluable information about the ML collections in 21 public libraries in Canada, as well as the attitudes of these libraries to proposed initiatives that would aid in expanding their ML collections. Although not affiliated with NLC, the present study follows in the footsteps of the NLC survey and Aerts's Survey of Multilingual Library Services in B[ritish] C[olumbia] (2000). Focusing on specific material types and specific acquisitions strategies, the present study aims to provide additional information about the current capabilities and future willingness of Canadian libraries to develop their ML collections.

\section{Purpose}

Accordingly, the broad purpose of this research is to determine the extent to which Canadian public libraries, at the beginning of the twenty-first century, are collecting ML materials and the methods that they use to select these materials. (The terms multilingual $[\mathrm{ML}]$ materials, foreign language materials, and non-English/non-French materials are used interchangeably throughout this article.) Do ML collections in Canadian public libraries reflect the declared principles of multiculturalism, and are public librarians sufficiently prepared and skilled to provide their ML clientele with an adequate array of library materials and services? The following five research questions were posed:

- Do Canadian public libraries want to shrink, maintain at current levels, or add to their collections of ML materials produced in the languages of the largest ML groups in their service areas?

- What are the biggest constraints that prevent Canadian public libraries from having ML materials?
- Do Canadian public libraries have electronic resources on their Web sites that would be of interest to the ML populations of their service areas?

- What tools and methods do Canadian public libraries use to select ML resources for the purposes of collection development?

- What measures are Canadian public libraries taking to determine what ML individuals in their service areas would like to see in their library collections?

\section{Method}

As mentioned above, Canada has two official languages: English and French. French speakers are concentrated to a very great extent in the province of Québec. This survey focuses on libraries in the English-speaking provinces and territories of Canada. According to The Bowker Annual 2001 (46th ed.), there are 1,615 public libraries in Canada, including branches (389). Of this number, 172 are in the Frenchspeaking province of Québec, as per the latest count in the 2001-02 edition of the American Library Directory (54th ed.). The number of libraries designated as public libraries in Québec was counted by hand from the American Library Directory. This number was then subtracted from the total figure of 1,615 provided by The Bowker Annual. Libraries in Québec were excluded from this survey. Using e-mail addresses supplied by the company Database Directories and its Canadian Libraries Database and Mailing List, we sent two rounds of e-mail messages, in March/April 2002, to the 1,443 (1,615 minus 172) Canadian public libraries in the nine English-language provinces and three territories asking them to fill out a Web-based survey about their collection development practices for ML materials. (Database Directories supplied more addresses than the number of libraries counted by The Bowker Annual 2001, but for the purposes of this research, we made the decision to take 1,443 as the correct number of public libraries in the Englishspeaking provinces and territories of Canada.) In addition, messages were posted to various provincial and national library association electronic discussion lists to remind librarians to complete the survey. The survey consisted of 10 questions, some with subdivisions. Five questions were answered by using either drop-down menus or radio buttons. Five questions were answered by fill-in-the-blank text boxes. The first question asked responding libraries to identify themselves as a sole unit library, a main branch, a branch of a system with one to five branches, a branch of a system with six to ten branches, or a branch system with more than ten branches, as well to state the population of their service area. The second question asked them to indicate their geographical location by province or territory. The third question 
asked them to list the three largest linguistic groups in their service area who have the ability to speak a language other than English or French, as well as the approximate sizes of those groups. Although we asked about geographical location by province/territory and sizes of foreign language groups, responses of libraries could not be verified using census data because we did not ask for a specific geographic town or city location within a province. Two subsequent questions inquired about how many items of various types (e.g., adult nonfiction, newspapers, children's books) the responding public library currently owned in its three designated non-English and non-French languages, as well as how many items of the same type each library would like to own. Another two questions inquired about the top three reasons why they did not have more materials in these languages and whether there were any other material types not previously mentioned that they would like to own.

The eighth question asked whether the responding library had, on its Web site, links to ML materials (e.g., newspapers, magazines, government documents) that may be of interest to foreign language patrons. In addition, it inquired about the presence or absence of character encoding software (e.g., Cyrillic, Chinese, Arabic) that allows people to read materials in languages written in non-Romanized scripts. The ninth question asked the libraries to identify the frequency with which they used 11 methods (e.g., local foreign language bookstores, Web sites of ML publishers) to enhance their foreign language collections. Finally, libraries were asked to indicate whether they were taking eight steps to enhance their links with foreign language community members. Ideas for questions were drawn from Guidelines for Multilingual Materials Collection and Development and Library Services, published by the American Library Association (1990), as well as from Multicultural Communities Guidelines for Library Services, published by the International Federation of Library Associations (IFLA 1998). The survey was pretested by one librarian and changes were made as a result of her suggestions. Trial surveys were submitted from various parts of the country to ensure that data was being collected in complete and usable form by the database software. Complete texts of these questions may be found in the appendix.

A total of 202 responses was received, of which 166 were usable, for a response rate of $11.5 \%$. Of the initial 202 responses, 25 were rejected because they indicated that French speakers were the primary ML group and 11 responses indicated that English speakers were the primary ML group. Although $11.5 \%$ is low, it must be remembered that the entire population, and not a sample, of Canadian public libraries was contacted. The geographic distribution of the 166 usable responses is as follows: Ontario (52), Alberta (29), British Columbia (29), Saskatchewan (18), Nova Scotia (13), New Brunswick (10), Manitoba (7),
Newfoundland (3), two each from Yukon and the Northwest Territories, and one from Prince Edward Island. Broad distribution of responses from across the country was therefore achieved, with 110 responses (66.3\%) coming from Ontario, Alberta, and British Columbia. According to the 2001 Canadian Census, the three most populous English-speaking provinces of Canada are Ontario, British Columbia, and Alberta, containing, respectively, $38 \%, 13 \%$, and $9.9 \%$ of the entire Canadian population (Statistics Canada 2001). Cumulatively, these provinces contain $60.9 \%$ of Canadian inhabitants. The distribution of responding libraries in the present survey therefore parallels, in general terms, the population distribution in Canada.

Of the 166 total responses, 165 described their library as follows: sole unit (50 [30.3\%]); main branch (40 [24.2\%]); branch of a system with five or fewer branches (20 [12.1\%]); and branch of a system with six or more branches (55 [33.3\%]). If we consider sole unit systems and all branches as examples of small or mid-sized libraries, then 125 responding libraries (75.8\%) could be classified as small or midsized. For 101 of the responding public libraries, the percentage of ML speakers in the library community service area could be calculated. Sixty-three $(62.4 \%)$ of the responding libraries were in communities where the population of ML speakers (of the largest foreign language group served) was less than $10 \%$ and 38 libraries (37.6\%) were in communities where the ML population (of the largest foreign language group served) was $10 \%$ or more. As shown in table 1, the 10 largest identified ML groups served by the responding public libraries were: German (37), Chinese (26), Dutch (14), Urdu/Punjabi (12), 9 each for Korean and Vietnamese, 8 each for Ukrainian and Italian, Japanese (7), and Polish (6). Even though the survey specifically asked for information about the languages of the three largest ML groups, the results reported below, unless indicated otherwise, speak only about the single largest ML group identified by responding libraries insofar as many responding libraries did not name more than one such group.

\section{Results}

\section{Shrinking, Maintaining, or Expanding the Collection?}

How do public libraries quantitatively view the state of their ML collections in the language of their largest ML community? To answer this question, we first asked libraries to state the number of items of various ML material types that they currently own; subsequently, we asked them how many items of the same material type they would like to own. We then subtracted the first number from the second number. If the result was positive, the library was deemed as wanting to expand its ML collection for this material type; if the result was negative, the library was deemed as wanting to 
either reduce (or remove completely) its ML collection for this material type; if the numbers matched, the library was deemed as wanting to maintain its ML collection for this material level at current levels.

As shown in table 2, in seven of the ten material types (reference books, newspapers, magazines, videos and DVDs, audiocassettes and CDs, ESL materials, and computer software), more than $50 \%$ of public libraries want to maintain such items at their current levels. For example, 101 libraries $(60.8 \%)$ want to maintain their newspaper collections at current levels, and 109 libraries (65.7\%) want to maintain their collections of videos and DVDs at current levels. In the categories of adult nonfiction (42.8\%) and children's books (46.4\%), a plurality of libraries want to maintain their collections at current levels, but there is an almost equal number of libraries who want to expand their collections: $38 \%$ want to expand their adult nonfiction holdings, while $43.4 \%$ wish to expand their children's collections. With regard to adult fiction, an almost equal number of libraries want to expand their adult fiction (41\%) as the number of libraries who wish to maintain adult fiction at current levels (39.8\%). On average, regardless of the type of item, $53.8 \%$ of libraries want to maintain their collections at current levels.

A small minority of libraries want to reduce or remove completely their collections (across all material types) in the language of their largest ML community. For example, only 17 libraries (10.2\%) want to decrease the number of, or remove, their children's books, and only 10 libraries (6\%) want to decrease the number of, or remove, their magazine collections. However, of all the material types listed in table 2 , adult fiction and adult nonfiction are the most susceptible to reduction or removal, with 32 libraries each (19.3\%) wanting to reduce the size of, or remove entirely, their adult fiction and adult nonfiction collections. In general, the desire to decrease the number of items, or remove them entirely, averages $12 \%(3.6 \%+8.4 \%)$, regardless of material type. To be fair, reducing may sometimes be seen as a positive activity, depending on whether new material is added to replace the eliminated material and whether the eliminated material is obsolete. But, as shown in table 2, for seven of the ten material types mentioned, the majority of libraries that want to decrease the size of their collections want to eliminate the entire collection (8.4\%); the exceptions are video and DVDs, audiocassettes and CDs, and computer software.

A greater number of public libraries want to add to their collections than want to reduce or remove them. As indicated in table 2, across all material types, $34.2 \%$ of responding libraries want to add ML materials. The two types of ML materials that the largest number of public libraries want to add more of are adult fiction and children's books. Seventy-two libraries (43.4\%) want to add more chil-
Table 1. Largest Foreign Language (Multilingual) Groups Served by Responding Libraries

\begin{tabular}{lclc}
\hline Language & Respondents & Language & Respondents \\
German & 37 & Aboriginal languages & 5 \\
Chinese & 26 & Portuguese & 5 \\
Dutch & 14 & Filipino & 3 \\
Urdu/Punjabi & 12 & Finnish & 2 \\
Korean & 9 & South Slavic & 2 \\
Vietnamese & 9 & Spanish & 2 \\
Italian & 8 & Gaelic & 1 \\
Ukrainian & 8 & Hebrew & 1 \\
Japanese & 7 & Hungarian & 1 \\
Polish & 6 & Norwegian & 1 \\
\hline
\end{tabular}

$n=159$

Table 2. What Do Libraries Want to Do with Items in the Language of Their Largest Foreign Language (Multilingual) Community?

\begin{tabular}{|c|c|c|c|c|c|c|}
\hline $\begin{array}{l}\text { Type of } \\
\text { material }\end{array}$ & $\begin{array}{l}\mathrm{Re} \\
\text { coll } \\
\text { No. }\end{array}$ & $\begin{array}{l}\text { duce } \\
\text { lection } \\
(\%)\end{array}$ & $\begin{array}{r}\text { Rer } \\
\text { er } \\
\text { colle } \\
\text { No. }\end{array}$ & $\begin{array}{l}\text { move } \\
\text { ntire } \\
\text { ection } \\
(\%)\end{array}$ & $\begin{array}{l}\text { No change } \\
\text { No. }(\%)\end{array}$ & $\begin{array}{l}\text { Expand } \\
\text { collection } \\
\text { No. (\%) }\end{array}$ \\
\hline $\begin{array}{c}\text { Reference } \\
\text { books }\end{array}$ & 6 & (3.6) & 18 & (10.8) & $84(50.6)$ & $58(34.9)$ \\
\hline Adult fiction & 6 & (3.6) & 26 & $(15.7)$ & $66(39.8)$ & $68 \quad(41)$ \\
\hline Adult nonfiction & 5 & (3) & 27 & $(16.3)$ & $71(42.8)$ & $63 \quad(38)$ \\
\hline Children's books & s 2 & $(1.2)$ & 15 & (9) & 77 (46.4) & $72(43.4)$ \\
\hline Newspapers & 0 & (0) & 9 & $(5.4)$ & $101(60.8)$ & $56(33.7)$ \\
\hline Magazines & 1 & $(0.6)$ & 9 & (5.4) & $92(55.4)$ & $64(38.6)$ \\
\hline $\begin{array}{l}\text { Videos and } \\
\text { DVDs }\end{array}$ & 6 & (3.6) & 4 & $(2.4)$ & $109(65.7)$ & $47(28.3)$ \\
\hline $\begin{array}{c}\text { Audiocassettes } \\
\text { and CDs }\end{array}$ & 10 & (6) & 10 & (6) & $95(57.2)$ & $51(30.7)$ \\
\hline ESL materials & 9 & $(5.4)$ & 14 & (8.4) & $88 \quad(53)$ & $55(33.1)$ \\
\hline $\begin{array}{l}\text { Computer } \\
\text { software }\end{array}$ & 14 & (8.4) & 8 & (4.8) & $110(66.3)$ & $34(20.5)$ \\
\hline Average \% & & 3.6 & & 8.4 & 53.8 & 34.2 \\
\hline
\end{tabular}

dren's books, and of these 72 libraries, 12 want to add 100 or more new titles. Sixty-eight libraries $(41 \%)$ want to add more adult fiction, and of these 68 libraries, 27 want to add 100 or more new titles. Fifty-eight libraries (34.9\%) want to add reference books, another 55 public libraries (33.1\%) want to add English as a Second Language (ESL) materials, 51 libraries (30.7\%) want to add audiocassettes and CDs, and 34 libraries $(20.5 \%)$ want to add computer software.

These results can be interpreted in two ways. When the percentage of libraries who want to expand their ML collections are added with the libraries who want to maintain their ML collections at current levels, the resulting figure is, on average and across all material types, an impressive $88 \%(53.8 \%+34.2 \%)$. On the other hand, on average and across all material types, $65.8 \%$ of all Canadian public libraries $(53.8 \%+12 \%)$ want to reduce or leave 
unchanged their ML collections. Just as the figure of $88 \%$ mentioned above sheds favorable light on libraries, the figure of $65.8 \%$ gives cause for concern, given the increasing presence of various ML groups in Canada.

The willingness of Canadian public libraries to reduce, or leave unchanged, their collections of materials in the language of their largest ML community extends across materials in all ML groups. Perhaps most surprising is the data provided by public libraries whose largest ML community served is the Chinese, one of the fastest-growing $\mathrm{ML}$ groups in Canada. As shown in table 3, across all material types, a majority of Canadian public libraries (50\% or more) wish to reduce or maintain at current levels their Chinese materials. The same general pattern is evident for various types of materials (with a few notable exceptions) produced in the Korean, Urdu/Punjabi, Vietnamese, and Japanese languages. In Urdu/Punjabi, these exceptions are adult nonfiction and children's books; in Vietnamese, these exceptions are adult fiction, children's books, magazines, and ESL materials; in Japanese, these exceptions are newspapers, magazines, and computer software.

On the other hand, as shown in table 4 , there is a general increase in the willingness of public libraries to expand their ML collections of materials produced in the language of the largest ML group served as the size of that ML group in the community increases. Of the 126 responding libraries providing appropriate data, libraries with service populations that have fewer than 300 individuals of the largest ML group served are the least willing to expand their ML collections in this language. For example, only $30 \%$ of this group of libraries wants to expand its ML children's and adult fiction collections in that language, and only $17.5 \%$ want to expand their ML newspaper collection in that language. Similar low figures pertain to magazines, videos and
DVDs, reference books, and audiocassettes and CDs. As the number of individuals of the largest ML group rises, so too does the commitment to expand the size of a library's ML collection in that language. This trend is most evident in the category of children's books and magazines. The percentage of public libraries willing to add more ML children's books increases from $30 \%$ to $50 \%$ to $52.4 \%$ to $66.7 \%$ as the population of the largest ML group rises past 300, then past 1,000 , and finally past 10,000 . The percentage of public libraries willing to add more ML magazines in that language increases from $20 \%$ to $50 \%$ to $52.4 \%$ to $61.1 \%$ as the population of the largest ML group rises past 300, then past 1,000 , and finally past 10,000 . Of course, there is not a perfect linear progression of this kind in all the material types; yet a general upward trend can be discerned for each material type. For example, while only $20 \%$ of public libraries want to add more reference materials when there are fewer than 300 individuals of the largest ML group served in the community, this figure increases to $46.2 \%$ in communities with populations of between 300 and 999, then dips slightly to $38.1 \%$ for communities with populations of between 1,000 and 10,000 , and then rises again to $50 \%$ for communities of more than 10,000. Willingness to add ML adult nonfiction materials rises from $22.5 \%$ to $57.7 \%$ before dipping to 44.4\%; willingness to add ML audiocassettes and CDs increases from $15 \%$ to $50 \%$; and willingness to add ML computer software increases from $12.5 \%$ to $61.1 \%$.

In addition, as shown in table 5 , when the percentage of ML speakers of the largest foreign language group served in the community that a library serves is $10 \%$ or more, public libraries, in general, are more willing to expand their ML collections in that language than when the percentage of ML speakers of the largest foreign language group served in the community is less than $10 \%$. In six of the material types, there

Table 3. Libraries Willing to Reduce or Leave Their Foreign Language (Multilingual) Collections Unchanged for the 10 Largest Foreign Language (Multilingual) Groups

\begin{tabular}{|c|c|c|c|c|c|c|c|c|c|c|c|c|c|c|c|c|c|}
\hline \multirow[t]{2}{*}{$\begin{array}{l}\text { Type of } \\
\text { material }\end{array}$} & \multicolumn{2}{|c|}{$\begin{array}{c}\text { German } \\
(n=37)\end{array}$} & \multicolumn{2}{|c|}{$\begin{array}{l}\text { Chinese } \\
(n=26)\end{array}$} & \multicolumn{2}{|c|}{$\begin{array}{l}\text { Dutch } \\
(n=14)\end{array}$} & \multicolumn{2}{|c|}{$\begin{array}{l}\text { Urdu/Punjabi } \\
\qquad(n=12)\end{array}$} & $\begin{array}{c}\text { Korean } \\
(n=9)\end{array}$ & \multicolumn{2}{|c|}{$\begin{array}{l}\text { Vietnamese } \\
\qquad(n=9)\end{array}$} & \multicolumn{2}{|c|}{$\begin{array}{l}\text { Italian } \\
(n=8)\end{array}$} & $\begin{array}{l}\text { Ukrainian } \\
\qquad(n=8)\end{array}$ & \multicolumn{2}{|c|}{$\begin{array}{c}\text { Japanese } \\
(n=7)\end{array}$} & $\begin{array}{l}\text { Polish } \\
(n=6)\end{array}$ \\
\hline & No. & $(\%)$ & No. & $(\%)$ & No. & (\%) & No. & $(\%)$ & No. (\%) & No. & (\%) & No. & (\%) & No. (\%) & No. & $(\%)$ & No. (\%) \\
\hline Reference books & 24 & $(64.9)$ & 19 & $(73.1)$ & 8 & $(57.1)$ & 7 & $(58.3)$ & $6 \quad(66.7)$ & 5 & $(55.6)$ & 7 & (87.5) & $(50)$ & 4 & $(57.1)$ & $4 \quad(66.7)$ \\
\hline Adult fiction & 18 & $(48.6)$ & 18 & (69.2) & 6 & (42.9) & 7 & $(58.3)$ & $8 \quad(88.9)$ & 4 & $(44.4)$ & 4 & (50) & $(50)$ & 5 & (71.4) & $5 \quad(83.3)$ \\
\hline Adult nonfiction & 23 & $(62.2)$ & 15 & $(57.7)$ & 7 & $(50)$ & 5 & (41.7) & $8 \quad(88.9)$ & 5 & $(55.6)$ & 4 & (50) & $5(62.5)$ & 4 & $(57.1)$ & $5 \quad(83.3)$ \\
\hline Children's books & 19 & (51.4) & 17 & (65.4) & 9 & (64.3) & 4 & (33.3) & $6 \quad(66.7)$ & 3 & (33.3) & 5 & $(62.5)$ & $3(37.5)$ & 4 & $(57.1)$ & $5 \quad(83.3)$ \\
\hline Newspapers & 26 & $(70.3)$ & 15 & $(57.7)$ & 8 & $(57.1)$ & 8 & $(66.7)$ & $6 \quad(66.7)$ & 5 & $(55.6)$ & 5 & $(62.5)$ & $(75)$ & 3 & $(42.9)$ & $4 \quad(66.7)$ \\
\hline Magazines & 23 & $(62.2)$ & 16 & $(61.5)$ & 9 & (64.3) & 6 & $(50)$ & $6 \quad(66.7)$ & 4 & $(44.4)$ & 3 & $(37.5)$ & $(50)$ & 3 & $(42.9)$ & $5 \quad(83.3)$ \\
\hline Videos and DVDs & 28 & $(75.7)$ & 20 & (76.9) & 10 & (71.4) & 7 & $(58.3)$ & $6 \quad(66.7)$ & 6 & $(66.7)$ & 4 & $(50)$ & $(50)$ & 6 & $(85.7)$ & $4 \quad(66.7)$ \\
\hline $\begin{array}{c}\text { Audiocassettes } \\
\text { and CDs }\end{array}$ & 24 & $(64.9)$ & 22 & (84.6) & 10 & (71.4) & 9 & $(75)$ & $6 \quad(66.7)$ & 5 & $(55.6)$ & 4 & (50) & $5 \quad(62.5)$ & 4 & $(57.1)$ & $4 \quad(66.7)$ \\
\hline ESL materials & 25 & $(67.6)$ & 17 & $(65.4)$ & 10 & (71.4) & 8 & $(66.7)$ & 7 (77.8) & 4 & $(44.4)$ & 5 & $(62.5)$ & $5(62.5)$ & 4 & $(57.1)$ & $5 \quad(83.3)$ \\
\hline $\begin{array}{l}\text { Computer } \\
\text { software }\end{array}$ & 30 & $(81.1)$ & 21 & (80.8) & 13 & (92.9) & 9 & $(75)$ & $6 \quad(66.7)$ & 7 & (77.8) & 4 & $(50)$ & $8 \quad(100)$ & 3 & (42.9) & $6 \quad(100)$ \\
\hline Average $\%$ & & 64.9 & & 69.2 & & 64.3 & & 58.3 & 72.2 & & 53.3 & & 56.3 & 60 & & 57.1 & 78.3 \\
\hline
\end{tabular}


is at least a $6 \%$ increase, in absolute terms, in the willingness to expand ML collections (reference books, adult nonfiction, children's books, videos and DVDs, ESL materials, and computer software). In two other material types (magazines and audiocassettes and CDs), willingness to expand ML collections increases by $4.6 \%$ in absolute terms. The findings from tables 4 and 5 make sense. Because public libraries are in the business of serving members of their community, it stands to reason that the greater the number of individuals speaking a specific ML language in that community, the greater the emphasis that public libraries will place on expanding their collections of materials in that language.

\section{Constraints to Acquiring More Multilingual Materials}

When public libraries were asked to name their top three constraints to acquiring more $\mathrm{ML}$ materials, the three biggest constraints in total, across all library types, were demand (mentioned by $29.2 \%$ of responding libraries), budget (mentioned by $25.9 \%$ ), and space (mentioned by $20.2 \%$ ). Availability of materials (12.5\%) and expertise (including cataloging expertise) (12\%) were somewhat lower down the list (see table 6). Many librarians wrote that lack of demand and low circulation figures create a situation in which potential costs of ML collection growth are not justified. Smaller libraries and library branches can obtain any ML materials requested by users through interlibrary loans from, for example, "a larger branch" or "a regional library." Accordingly, these libraries see no need to accumulate significant amounts of ML materials in their own locations. The "no need" notion derives from two basic factors: a very small number of users requesting materials in ML languages and a lack of interest on the part of ML speakers in reading their own languages even when the ML community size is large. As some respondents emphasized, many ML speakers are already fluent in English, or are "wishing to become so." Second and third generations of immigrants are "thoroughly Canadian," and thus have almost no interest in borrowing materials in their mothertongue languages. In addition, recent immigrants are "more interested in integrating themselves and their children into Canadian life" (and are therefore "anxious to learn one or both official languages") than in demanding materials in
Table 5. Libraries Willing to Expand Their Foreign Language (Multilingual) Collection of Their Largest Foreign Language Group Served by Percentage of Foreign Language (Multilingual) Speakers of the Largest Foreign Language Group Served in Their General User Population

\begin{tabular}{|c|c|c|c|c|}
\hline \multirow[t]{2}{*}{ Type of material } & \multicolumn{2}{|c|}{ Less than $10 \%(n=63)$} & \multicolumn{2}{|c|}{$10 \%$ or more $(n=38)$} \\
\hline & No. & (\%) & No. & (\%) \\
\hline Reference books & 14 & $(22.2)$ & 16 & $(42.1)$ \\
\hline Adult fiction & 27 & $(42.9)$ & 14 & $(36.8)$ \\
\hline Adult nonfiction & 26 & $(41.3)$ & 18 & $(47.4)$ \\
\hline Children's books & 23 & $(36.5)$ & 17 & (44.7) \\
\hline Newspapers & 23 & $(36.5)$ & 12 & $(31.6)$ \\
\hline Magazines & 22 & $(34.9)$ & 15 & $(39.5)$ \\
\hline Videos and DVDs & 13 & $(20.6)$ & 13 & $(34.2)$ \\
\hline Audiocassettes and CDs & 17 & $(27.0)$ & 12 & $(31.6)$ \\
\hline ESL materials & 15 & $(23.8)$ & 16 & $(42.1)$ \\
\hline Computer software & 9 & $(14.3)$ & 14 & $(36.8)$ \\
\hline
\end{tabular}

their language of origin. Respondents mentioned situations where Italian, Asian, and Spanish language collections in their libraries amounted to what can best be described as unutilized ballast. One respondent described how the German language collection in her or his library was eventually dismantled and donated to the local population.

Ironically, a lack of demand can, as one respondent phrased it, turn out to be a "good thing" for public libraries, since library staff have "no ability to function in these [foreign] languages." Many respondents pointed out that, because staff members do not have knowledge of ML languages, it is inevitable that they show "ignorance of resources available" for the purposes of selection and purchase of materials in these languages. Accordingly, the lack of ability to speak, read, and write ML languages undermines the expertise and performance of public librarians in such areas as collection development, acquisitions, and cataloging. It also hampers their contacts with ML communities because they have great difficulty in discovering "what would be popular." Lack of expertise is often complicated 
Table 6. Main Constraints Preventing Public Libraries from Having More Foreign Language (Multilingual) Materials by Library Type

\begin{tabular}{lcccccc}
\hline Type of library & Demand & Budget & Space & Availability & Expertise & Prejudice \\
Sole unit & 30 & 28 & 23 & 13 & 14 & 0 \\
$\begin{array}{l}\text { Main branch } \\
\text { Branch of a system with }\end{array}$ & 23 & 26 & 19 & 16 & 15 & 0 \\
$\quad$ five or fewer branches & & 10 & 8 & 9 & 6 & 0 \\
$\begin{array}{l}\text { Branch of a system with } \\
\quad \text { six or more branches }\end{array}$ & 36 & 31 & 24 & 8 & 9 & 1 \\
$\begin{array}{l}\text { Total } \\
n=367 \text { (multiple answers allowed) }\end{array}$ & & & & & & \\
\hline
\end{tabular}

by a scarcity of, and difficulty in, obtaining ML selection tools to the point that some librarians think "they do not exist." Finally, because many libraries have limited funds, they are cautious about spending money on materials that are not expected to be used to any great extent. Indeed, a number of respondents stressed "fighting for our lives in terms of just basic funding" to acquire a sufficient number of English-language materials.

\section{Online Multilingual Materials}

When asked whether they had links to ML materials such as newspapers, magazines, and government documents that could be of interest to individuals speaking the three most popular non-English languages in the library's service area, only 9 libraries $(6.1 \%)$ said that they had 5 or more such links (see table 7). Another 21 libraries (14.2\%) said that they currently had five or fewer such links, but indicated that they would like to have more in the future. Fifty-three libraries $(35.8 \%)$ admitted that, although they did not currently have such links, they nevertheless would like to have some. Given the fact that, according to the 1996 Canadian Census, there are more than 2.5 million individuals in Canada who identify themselves as speaking a language other than English or French at home, the lack of ML links on library Web sites is perplexing. Even more perplexing, in light of the above, is the fact that 65 public libraries (43.9\%), of all sizes and types, indicated that they saw "no need" to have links to ML newspapers and magazines on their Web sites.

Often, especially those languages written in such nonRomanized scripts as Chinese, Ukrainian, Punjabi, Vietnamese, and Urdu, foreign languages can only be read in the electronic medium with the aid of character encoding software (table 8). As the 1996 Census states, there are more than 500,000 individuals who speak Chinese at home, more than 200,000 who speak Punjabi at home, and just under 100,000 individuals who speak Vietnamese at home (Statistics Canada, 1996a). These figures are likely to increase in the 2001 Census. However, despite the large presence of $\mathrm{ML}$ speakers, only $21(6+15)$ public libraries (14.3\%) currently have characterencoding software on their Web sites to enable foreign languages to be read (see table 8). Another 43 libraries $(29.3 \%)$ note that, while they do not have such software now, they would like to include one or more such character encodings on their sites in the near future. Yet the majority of libraries (83 [56.5\%]) indicate that they have "no need" to load such software onto their servers. Taken together with the $43.9 \%$ of public libraries who do not want to have links to ML newspapers or magazines, the lack of enthusiasm for character encodings may be a sign that much work still needs to be done towards making public libraries welcoming places for ML users. Moreover, if a public library wants to allow its users who speak languages written in nonRomanized scripts to send e-mails in their own languages, or if a public library wants to enable users to display its Web pages in non-Romanized scripts and search these pages using search terms written in non-Romanized scripts, then additional work with keyboard options, character encoding, and, possibly, translation software needs to be done by library personnel.

\section{Selection Methods for Multilingual Materials}

As shown in table 9, a large majority of public libraries never use the 11 selection methods identified: printed catalogs of foreign language publishers; Web sites of foreign language publishers; Web sites that review foreign language materials; local foreign language specialty bookstores; foreign language bookstores in another North American city; bookstores in the country where this language is spoken; Web sites of foreign language bookstores anywhere in the world; library staff who speak this language; library volunteers who speak this language; local people who speak this language; and approval plans. (Data in tables 9 and 10 are based on the "finding out about printed material in this foreign language" column of Survey Question 9 in the appendix.) Moreover, those libraries that do use these methods use them on a very infrequent basis, for the most part only "about once or twice a year." As shown in table 10, the most popular selection methods for the 10 largest ML groups are, in order, printed catalogs of foreign language publishers (33), approval plans (31), and local people who speak this language 
(27). Far down the list are such methods as local foreign language bookstores (15), bookstores in the country where this language is spoken (13), and Web sites of foreign language bookstores anywhere in the world (6). Nevertheless, some of the less popular methods listed in tables 9 and 10 are relatively accessible. Public libraries who are serious about wishing to improve the state of their ML collections should be exploring a number of these avenues.

\section{Other Measures Taken by Public Libraries to Improve Multilingual Collections}

In the same way that many Canadian public libraries see no need to link electronically to online ML newspapers and magazines, load non-Roman alphabet character encoding software onto their servers, or make use of a wide array of selection strategies, so too it appears that many of them do not see the need to adopt any of the eight strategies listed in table 11 to improve their ML services that have either a direct or indirect bearing on ML collections. Indeed, for six of these eight strategies, the majority of public libraries are content to do nothing. For example, 87 libraries $(52.4 \%)$ do not have any paid staff who work 20 or more hours and who speak any of the top three ML languages spoken in that library's service area, and 111 libraries (66.9\%) do not have any volunteers who speak any of these ML languages. Equally problematic is that 101 Library Type Type
Table 7. Availability of Online Materials in Foreign (Non-English and Non-French) Languages by

\begin{tabular}{|c|c|c|c|c|}
\hline Type of library & $\begin{array}{l}\text { Ne have many } \\
\text { (5 or more) }\end{array}$ & $\begin{array}{l}\text { We have a few } \\
\text { (less than 5), but } \\
\text { would like more }\end{array}$ & $\begin{array}{l}\text { We don't have any now, } \\
\text { but would like to have } \\
\text { some }\end{array}$ & No need to have any \\
\hline Sole unit & 1 & 8 & 17 & 17 \\
\hline Main branch & 3 & 3 & 18 & 15 \\
\hline $\begin{array}{l}\text { Branch of a system with } \\
\text { five or fewer branches }\end{array}$ & h & 2 & 3 & 13 \\
\hline $\begin{array}{l}\text { Branch of a system with } \\
\text { six or more branches }\end{array}$ & 4 & 8 & 15 & 20 \\
\hline $\begin{array}{l}\text { Total } \\
n=148\end{array}$ & $9(6.1 \%)$ & $21(14.2 \%)$ & $53 \quad(35.8 \%)$ & $65(43.9 \%)$ \\
\hline
\end{tabular}

Table 8. Availability of Encoding Support for Non-Romanized Scripts on Library Web Sites by Library

\begin{tabular}{|c|c|c|c|c|}
\hline Type of library & $\begin{array}{l}\text { We have many } \\
\text { ( } 5 \text { or more) }\end{array}$ & $\begin{array}{l}\text { We have a few } \\
\text { (less than 5), but } \\
\text { would like more }\end{array}$ & $\begin{array}{l}\text { We don't have any now, } \\
\text { but would like to have } \\
\text { some }\end{array}$ & No need to have any \\
\hline Sole unit & 3 & 7 & 12 & 21 \\
\hline Main branch & 1 & 3 & 19 & 16 \\
\hline $\begin{array}{l}\text { Branch of a system with } \\
\text { five or fewer branches }\end{array}$ & s & 2 & 2 & 12 \\
\hline $\begin{array}{l}\text { Branch of a system with } \\
\text { six or more branches }\end{array}$ & 0 & 3 & 10 & 34 \\
\hline $\begin{array}{l}\text { Total } \\
n=147\end{array}$ & $6(4.1 \%)$ & $15(10.2 \%)$ & $43 \quad(29.3 \%)$ & $83(56.5 \%)$ \\
\hline
\end{tabular}

Table 9. Frequency of Methods Used for Selecting (Finding Out About) Foreign-Language (Multilingual) Materials by All Respondents

\begin{tabular}{|c|c|c|c|c|}
\hline $\begin{array}{l}\text { Selection } \\
\text { method }\end{array}$ & Never & $\begin{array}{l}\text { About once or } \\
\text { twice per year }\end{array}$ & $\begin{array}{l}\text { About 3-7 times } \\
\text { per year }\end{array}$ & $\begin{array}{l}\text { About once } \\
\text { a month }\end{array}$ \\
\hline $\begin{array}{l}\text { Printed catalogs of foreign } \\
\text { language publishers }\end{array}$ & 127 & 16 & 15 & 8 \\
\hline $\begin{array}{l}\text { Web sites of foreign language } \\
\text { publishers }\end{array}$ & 145 & 9 & 9 & 3 \\
\hline $\begin{array}{l}\text { Web sites that review foreign } \\
\text { language materials }\end{array}$ & 148 & 8 & 8 & 2 \\
\hline $\begin{array}{l}\text { Local foreign language specialty } \\
\text { bookstores }\end{array}$ & 146 & 11 & 8 & 1 \\
\hline $\begin{array}{l}\text { Foreign language bookstores in } \\
\text { another North American city }\end{array}$ & 140 & 17 & 7 & 2 \\
\hline $\begin{array}{l}\text { Bookstores in the country where } \\
\text { this foreign language is spoken }\end{array}$ & 151 & 11 & 2 & 2 \\
\hline $\begin{array}{l}\text { Web sites of foreign language } \\
\text { bookstores anywhere in the world }\end{array}$ & 159 & 4 & 2 & 1 \\
\hline Library staff who speak this language & 148 & 13 & 3 & 2 \\
\hline $\begin{array}{l}\text { Library volunteers who speak this } \\
\text { language }\end{array}$ & 153 & 7 & 6 & 0 \\
\hline Local people who speak this language & 132 & 20 & 7 & 7 \\
\hline $\begin{array}{l}\text { Approval plans used by my library } \\
n=166\end{array}$ & 131 & 18 & 1 & 16 \\
\hline
\end{tabular}

responding libraries $(60.8 \%)$ have not had at least three diversity training sessions in the past year where staff are instructed in such things as cross-cultural communication 
Table 10. Most Popular Methods of Selecting (Finding out about) Foreign Language (Multilingual) Materials That Are Used at Least Once a Year for the 10 Largest Foreign Language (Multilingual) Groups

\begin{tabular}{|c|c|c|c|c|c|c|c|c|c|c|c|}
\hline Selection method & German & Chinese & Dutch & $\begin{array}{l}\text { Urdu/ } \\
\text { Punjabi }\end{array}$ & Korean & Vietnamese & Italian & Ukrainian & Japanese & Polish & Total \\
\hline $\begin{array}{l}\text { Printed catalogs of } \\
\text { foreign language } \\
\text { publishers }\end{array}$ & 8 & 10 & 3 & 3 & 1 & 1 & 3 & 2 & 1 & 1 & 33 \\
\hline $\begin{array}{l}\text { Approval plans used } \\
\text { by my library }\end{array}$ & 11 & 7 & 4 & 2 & 0 & 1 & 2 & 1 & 2 & 1 & 31 \\
\hline $\begin{array}{l}\text { Local people who speak } \\
\text { this foreign language }\end{array}$ & 11 & 3 & 3 & 4 & 0 & 1 & 3 & 0 & 1 & 1 & 27 \\
\hline $\begin{array}{l}\text { Foreign language } \\
\text { bookstores in another } \\
\text { North American city }\end{array}$ & 4 & 6 & 3 & 2 & 1 & 1 & 2 & 0 & 2 & 2 & 23 \\
\hline $\begin{array}{l}\text { Web sites of foreign } \\
\text { language publishers }\end{array}$ & 4 & 7 & 0 & 2 & 0 & 0 & 3 & 1 & 0 & 2 & 19 \\
\hline $\begin{array}{l}\text { Web sites that review } \\
\text { foreign language } \\
\text { materials }\end{array}$ & 7 & 5 & 1 & 1 & 1 & 0 & 1 & 0 & 0 & 1 & 17 \\
\hline $\begin{array}{l}\text { Local foreign language } \\
\text { specialty bookstores }\end{array}$ & 4 & 3 & 2 & 1 & 0 & 2 & 1 & 0 & 2 & 0 & 15 \\
\hline $\begin{array}{l}\text { Library staff who speak } \\
\text { this language }\end{array}$ & 4 & 4 & 1 & 2 & 0 & 0 & 2 & 1 & 0 & 1 & 15 \\
\hline $\begin{array}{l}\text { Bookstores in the country } \\
\text { where this language is } \\
\text { spoken }\end{array}$ & 2 & 5 & 0 & 2 & 0 & 1 & 1 & 0 & 0 & 2 & 13 \\
\hline $\begin{array}{l}\text { Library volunteers who } \\
\text { speak this language }\end{array}$ & 2 & 3 & 1 & 2 & 0 & 0 & 0 & 0 & 1 & 0 & 9 \\
\hline $\begin{array}{l}\text { Web sites of foreign } \\
\text { language bookstores } \\
\text { anywhere in the world }\end{array}$ & 1 & 4 & 0 & 1 & 0 & 0 & 0 & 0 & 0 & 0 & 6 \\
\hline
\end{tabular}

patterns, and the same number of libraries (101) have not conducted an ML user survey. Still, it is encouraging to find that 61 libraries $(37 \%)$ have a mechanism that allows ML speakers to make suggestions about how the library can improve service to them, and that another 31 libraries (18.8\%) are either working on implementing such a mechanism or are aware that they need one. In addition, 34 libraries $(20.5 \%)$ have put together a collection of resources on diversity and multiculturalism, 47 libraries (28.7\%) have developed community outreach partnerships with ML groups to shape collection development policies, and another 28 libraries $(17 \%)$ are either working on implementing such outreach partnerships or are aware that they need to do so.

Just as public libraries were more willing to expand the size of their ML collections if they served a population area that had large numbers of ML groups (see tables 4 and 5), so it is also the case that public libraries are more willing to move forward with the eight actions listed in table 11 when the largest foreign language group served constitutes $10 \%$ or more of their general user population. As shown in table 12, the percentage of libraries not willing to undertake five of these actions_-including hiring paid staff who speak ML languages, hiring volunteers who speak ML languages, imple- menting diversity training, conducting needs assessments, and developing outreach initiatives - falls when the percentage of foreign language speakers (of the largest foreign language group served) in their general user population is $10 \%$ or more. For instance, while $58.7 \%$ of libraries with ML populations of less than $10 \%$ do not see a need to hire ML staff, only $44.7 \%$ of libraries with ML populations of $10 \%$ or more see no need to hire staff who speak ML languages. Although this is a marked improvement, it is still true that $44.7 \%$ of responding libraries that have $10 \%$ or more foreign language speakers in their general user population see no need to hire staff who speak ML languages. The same pattern can be seen with engaging volunteers who speak ML languages. Although the percentage of libraries not wishing to engage such volunteers drops (from $77.8 \%$ to $60.5 \%$ ) when a library serves a population consisting of $10 \%$ or more of ML speakers, $60.5 \%$ of public libraries are nevertheless not willing to engage such volunteers. Libraries are unwilling to undertake two actions - making available a collection of staff development resources on diversity and multiculturalism and conducting user surveys - at about the same rates regardless of the percentage of ML speakers (of the largest foreign language group served) in the general user population. 
Table 11. Actions Undertaken by Public Libraries to Meet the Needs of Their Foreign Language (Multilingual) Clientele

\begin{tabular}{|c|c|c|c|c|c|c|c|}
\hline Actions & \multicolumn{2}{|c|}{ Yes } & \multicolumn{2}{|c|}{$\begin{array}{l}\text { We're working on } \\
\text { implementing this } \\
\text { within the next year } \\
\text { No. (\%) }\end{array}$} & \multicolumn{2}{|c|}{$\begin{array}{l}\text { We're aware we } \\
\text { need to do this, but } \\
\text { right now we don't } \\
\text { have the time or } \\
\text { the money to do it } \\
\text { No. (\%) }\end{array}$} & $\begin{array}{l}\text { There is no need } \\
\text { and no plans } \\
\text { for us to do this } \\
\text { No. (\%) }\end{array}$ \\
\hline $\begin{array}{l}\text { Do you have any paid staff who work } 20 \text { or more hours in } \\
\text { your library who speak any of the top three foreign languages } \\
\text { spoken in your service area? }(n=166)\end{array}$ & 43 & $(25.9)$ & & 0 & 36 & $(21.7)$ & $87 \quad(52.4)$ \\
\hline $\begin{array}{l}\text { Do you have any library volunteers who speak any of the top } \\
\text { three foreign languages spoken in your service area? }(n=166)\end{array}$ & 22 & (13.3) & 3 & $(1.8)$ & 30 & $(18.1)$ & 111 (66.9) \\
\hline $\begin{array}{l}\text { Has your library put together a collection of staff development } \\
\text { resources (videos, pamphlets, etc.) on issues of diversity and } \\
\text { multiculturalism? }(n=166)\end{array}$ & 34 & $(20.5)$ & 3 & $(1.8)$ & 48 & $(28.9)$ & $81 \quad(48.8)$ \\
\hline $\begin{array}{l}\text { Does your library provide diversity training sessions (at least } \\
3 \text { in the past year) to staff? Diversity training courses provide } \\
\text { instruction in such things as crosscultural communication } \\
\text { and so on. }(n=166)\end{array}$ & 17 & $(10.2)$ & 1 & $(0.6)$ & 47 & $(28.3)$ & $101 \quad(60.8)$ \\
\hline $\begin{array}{l}\text { Has your library conducted a formal needs assessment study } \\
\text { about non-English and non-French language speakers in } \\
\text { your community? }(n=166)\end{array}$ & 21 & $(12.7)$ & 1 & $(0.6)$ & 47 & $(28.3)$ & $97 \quad(58.4)$ \\
\hline $\begin{array}{l}\text { Has your library conducted a user-survey targeting non-English } \\
\text { and non-French speakers in your community? }(n=166)\end{array}$ & 21 & $(12.7)$ & 1 & $(0.6)$ & 43 & $(25.9)$ & $101 \quad(60.8)$ \\
\hline $\begin{array}{l}\text { Do you have a mechanism that allows foreign language speakers } \\
\text { to make suggestions about how your library can improve } \\
\text { service to them? }(n=165)\end{array}$ & 61 & (37) & 2 & $(1.2)$ & 29 & $(17.6)$ & $73 \quad(44.2)$ \\
\hline $\begin{array}{l}\text { Has your library developed community outreach partnerships } \\
\text { with various non-English and non-French cultural groups to } \\
\text { help shape collection development policy in your library? } \\
(n=164)\end{array}$ & 47 & $(28.7)$ & 4 & (2.4) & 24 & $(14.6)$ & $89 \quad(54.3)$ \\
\hline
\end{tabular}

Table 12. Libraries Seeing No Need to Undertake Actions to Improve Collections for Their Foreign Language (Multilingual) Clientele by Percentage of Foreign Language Speakers of the Largest Foreign Language Group Served in Their General User Population

\section{Actions}

Hire paid staff (20 or more hours per week) who speak foreign languages

Engage library volunteers speaking foreign languages

Make available a collection of staff development resources on diversity and multiculturalism

Implement diversity training

Conduct a formal needs assessment

Conduct a user survey

Implement a mechanism for foreign language speakers to make suggestions

Develop community outreach initiatives to foreign language groups to help in collection development

$*_{n}=62$

$* * n=37$

$\begin{array}{cc}\begin{array}{c}\text { Less than } \\ \text { No. }\end{array} & (\%) \\ 37 & (58.7) \\ 49 & (77.8) \\ 32 & (50.8) \\ & \\ 41 & (65.1) \\ 38 & (60.3) \\ 36 & (57.1) \\ 25 & (40.3)^{*} \\ 37 & (58.7)\end{array}$

$\begin{array}{cc}10 \% \text { or more }(n=38) \\ \text { No. } & (\%) \\ 17 & (44.7) \\ 23 & (60.5) \\ 21 & (55.3) \\ & \\ 22 & (57.9) \\ 21 & (55.3) \\ 24 & (63.2) \\ 22 & (57.9) \\ 18 & (48.7)^{* *}\end{array}$

\section{Limitations}

There are a number of limitations to this study. The low response rate of $11.5 \%$ makes the results presented here tenuous; they may not be able to be generalized. Because $75.8 \%$ of responses were received from sole unit libraries or branches, the reality of large central systems may be not adequately represented. In addition, there were no responses from public libraries serving, for example, the Spanish or Arabic communities. Public libraries serving German populations may be overrepresented given the fact that, according to the 1996 Census, there are only 114,085 individuals who declared German as their home language, while there are 586,085 individuals who declared Chinese as their home language (Statistics Canada 1996a). This may be an accident of response, or it may be an indication that 
librarians in some locations were unaware of, or unwilling to complete, this survey. Finally, some large metropolitan public library systems have policies where the main branch reports on behalf of all other branches. Other systems allow their branches to respond individually to surveys. Thus, the results provided by a library system that has a wealth of ML resources but only reports once as a complete entity may be statistically submerged by results coming from individual branches of another library system that may not necessarily have ML resources at all its branches. Nevertheless, the results gathered here should be seen as a sign, however imperfect, that some public libraries in Canada may find themselves to be in a situation where they are unable to provide ML collections and services at a sufficient level.

\section{Discussion}

One way to interpret these results is to see a relationship between, on the one hand, the fact that a significant number of Canadian public libraries are not undertaking hiring, outreach, and diversity training initiatives of the type listed in table 11 and, on the other hand, the relatively poor outcomes that these libraries show with regard to employing a wide variety of selection tools to expand their ML collections. If public library collection development personnel do not know very much about, or do not make extensive use of, the various selection methods listed in table 9 , it would be difficult indeed to expand their ML collections in the various material types listed in tables 2-5. Some support for this assertion is provided in table 6 , where $12.5 \%$ of libraries state that perceived lack of availability of ML materials deters them from having a greater number of such materials. Even if librarians do know about the various collection development methods listed in table 9, they may not be able to use them because they lack reading knowledge of foreign languages or other expertise. As shown in table 6, lack of expertise was mentioned as a constraint on ML collection development by $12 \%$ of respondents. In addition, the lack of willingness to make available ML online materials (table 7) and character encoding software for non-Romanized scripts (table 8) suggests that Canadian public libraries are not doing as much as they could in terms of creating an inviting atmosphere for ML clients.

Of course, it may also be the case that many libraries lack adequate budgets to collect ML materials at a level that matches the needs of their communities. Our findings show that $25.9 \%$ of surveyed libraries stated that budgetary constraints inhibited development of their ML collections (table 6 ). As noted above, the NLC survey found that 10 out of 21 library systems in relatively large metropolitan areas either had no budget (three libraries) or an inadequate budget (seven libraries) for ML materials (Multicultural
Resources and Services 2002, 1, 5, 6, 7, 8, 10, 13). Rajwant Chilana (2001), while praising the efforts of the Fraser Valley Regional Library (in British Columbia) in providing materials and services in such languages as Punjabi, Hindi, and Chinese, nevertheless notes that, in an era of "diminishing budgets" and "increasing demands from users for quality services," "there is an increasing pressure on our staff to justify/review the size, growth rate, and content of non-English language collections," in other words, to be "fiscally responsible" without losing sight of cultural and linguistic diversity (19-20).

Moreover, as indicated in table 6 , the perceived lack of demand for ML materials is an inhibiting factor for many public libraries in their decisions not to increase the size of their ML collections. But, as the Multilingual Materials Subcommittee (1990) of the ALA points out, lack of demand may be a function of previous inadequate service and the perception, on the part of ML communities, that public libraries have nothing to offer them. As Gitner (1998) explains, the Queens Borough Public Library (QBPL) runs a successful "New Americans" program that offers "a unique mix of interrelated programs, services, and collections designed to reach" individuals speaking more than 100 different languages through a "proactive approach" (emphasis added) that includes "personal contacts by phone and in-person to local community agencies, attendance at community fairs, and press releases to the ethnic media" (143-44). In other words, QBPL is creating demand by "let[ting] immigrants know that the library welcomes them and has many programs and services to offer them and their families" (144). Moreover, in the area of collection development, QBPL goes out of its way to "provide general popular materials from their home countries on the same topics that we provide our English-speaking customers, i.e., fiction, parenting, cookbooks, biographies, romances, children's books, videos, and music CDs" as a way of assuring its diverse clientele that "it respects their native culture, language, and customs" (145). In addition, it has instituted a "Mail-a-Book" program in seven languages, defined as "annotated lists of about one hundred titles each that act as a public-relations tool and allow customers to become acquainted with the library" without having to physically come to the library (145). Certainly, as the NLC survey makes clear, numerous large public libraries in Canadian metropolitan areas have substantial collections of non-English materials in such diverse languages as Bosnian, Chinese, Farsi, Hindi, Portuguese, Russian, and others (Multicultural Resources and Services 2002). And in 2000, the Toronto Public Library increased its French and multilingual materials budget to $\$ 1.5$ million, or $12 \%$ of the budget (Toronto Public Library 2001). In addition, it has implemented "a resource deposit model for its circulating French and multilingual collections," whereby "142 large 
resource collections [that] are located at District and larger branches with language communities . . . supply material for approximately 350 smaller collections at Neighbourhood branches where needed," and it also provides access to over 500 multilingual magazines and newspapers in "over 70 languages via the Newsconnect Gateway on the Virtual Reference Library" (2-3). It is encouraging, moreover, to see that, in general, as the size of the largest foreign language group served increases, public libraries are willing to increase the size of their ML collections in that language (tables 4 and 5). Nonetheless, some of the public libraries that responded to the present survey had an ambiguous relationship with the concept of ML collections, especially when it comes to finding out about (selecting) print materials in foreign languages and establishing electronic collections in foreign languages.

Why might this be so? Public libraries, for all intents and purposes, reflect the knowledge, worldviews, energy, and initiatives of their staff members. Staff members, both professional and paraprofessional, are, in turn, influenced, to some extent at least, by the emphases placed on different values and outlooks in the various institutions offering degree programs in library and information science (LIS). It may very well be that, at a time when technological, electronic, and digital concerns are given pride of place in the curriculum, issues directly pertaining to the development and expansion of ML collections and services in libraries and other information organizations are not receiving the kind of primary, concerted, and obligatory attention that they deserve.

Identifying demographic trends in the United States whereby Hispanic and Asian populations will account for the major portion of population growth in the next 20 years, Nance-Mitchell (1996) called for a rapid increase in the number of minority librarians recruited and retained in LIS programs. Gollop (1999) concurred, but also noted that LIS programs "must make every effort to prepare all their graduates to work in larger multicultural environments [even if] such preparation may mean altering several courses in a school's curriculum" (385). Gollop's emphasis on the word "all" springs from her realization that students who have an initial interest in multiculturalism and diversity issues will "usually self-select and enroll in courses that have a broader cultural perspective . . . but that students who do not necessarily hold such an interest will apply their precious credit hours to taking other courses" (390). But, in light of demographic trends, those latter students may increasingly "find themselves ill prepared for encounters with library patrons who are very different from themselves [because the students] possess little knowledge of how best to respond to and bridge those differences" (390). Basing her proposals on the work of Lorna Peterson, she therefore suggests "organizing units in a given course ... around multicultural diversity issues" so that all students, no matter what courses they elect to take, are deliberately and systematically exposed to multicultural issues in a variety of contexts and situations (390).

This recommendation is all the more pertinent when seen in the context of two other studies. First, East and Lam (1995) found that, when LIS schools were asked whether any planned single course on multiculturalism would have required, highly recommended, recommended, or optional status, only one school (out of 17) said it would be required, while nine schools (out of 17) said it would be optional (207). Second, Peterson (1999) observed that "courses described as devoted to diversity [in the curricula of LIS schools] were generally reported as experimental with low enrollments" (24) and that four schools had recently dropped multicultural courses (although three schools had added experimental courses). Single optional courses about multicultural librarianship therefore do not seem to work as well as they might. Even if LIS schools adopt such courses, making them optional rather than required typically guarantees low enrollments-a state of affairs that contributes to the eventual demise of such courses in an academic atmosphere where devoting resources and energy to courses that only attract a handful of students is frowned upon.

Yet multicultural and multilingual issues pervade every aspect of library and information work. For example, as Chu (2000) observes, all media, including electronic media, are nonneutral. Indeed, many multimedia resources that purport to be multicultural are "developed in the western world . . . by middle-class white males" and thus reflect "a very limited selection of the universe of knowledge ... and a particular vision of legitimate knowledge and culture" (255-56). Accordingly, librarians, among others, must be sensitive to a wide range of evaluative criteria-including such ideas as invisibility, fragmentation, language variance, and language bias-when developing, maintaining, and weeding multimedia resources. If such sensitivity and knowledge are called for when dealing with multicultural materials produced in English, the knowledge and sensitivity required when dealing with materials produced in languages other than English is equally great, if not greater.

What specific types of knowledge should librarians be gaining about multilingual populations? First, as recognized by Berry, Kim, and Boski (1988), there must be an awareness of the various "psychological acculturation" processes of multilingual groups (e.g., integration, assimilation, separation, and marginalization), as well as an understanding that, beyond their linguistic differences, multilingual groups can be divided into five subcategories: immigrants; refugees; native peoples; ethnic groups; and sojourners (62-66), each with their own unique characteristics. Mylopoulos (2000), explaining that there are three stages of 
the settlement process of immigrants (an orientation stage; an intermediary stage focused on "longer-term resettlement"; and a final stage centered on "how one can get reliable and understandable information on a consistent basis"), argues that librarians should recognize that information must be provided in "a contextual way" so that it meets "the everyday lives of people" who often live in "small worlds" (27). Freiband (1992) observes that librarians must have the knowledge necessary to "develop collections on an international level," which means a ready acquaintance with "ethnic and minority publishers and producers of library materials," and the ability "to communicate directly with these groups in their own languages and to recognize cultural differences in nonverbal communications patterns" (288-89). A World of Information mentioned that knowing about literary and publishing trends in foreign countries is something that should become an important part of the intellectual toolkit of library staff (NLC 1994). These last points speak eloquently about the pressing need to train existing and future library staff in $\mathrm{ML}$ language skills and cultural phenomena-a humanistic approach to library education that is, unfortunately, fast becoming outmoded. These points also speak forcefully about the necessity to proactively recruit ML speakers into LIS programs and to offer them a structured and far-reaching program of study that emphasizes ML concerns in every course taken.

One education model that recognizes that librarians must have broad-based knowledge about cultural phenomenon and multilingual abilities in order to serve diverse populations is the Israeli retraining program for professional librarians immigrating from Russia. As described by Lazinger and Peritz (1993), this program starts from the premise that if Russian-educated librarians are to serve Israeli library patrons adequately, they must not only know about computer technologies and processes, but must also be well versed about cultural matters. The program thus consists of 600 hours of study, which includes 40-hour courses in Modern Hebrew Literature, Modern Jewish History, Jewish Bibliography, and a 100-hour course in Hebrew. Certainly, the specific intent of this program is farremoved from the Canadian situation, but its general principles can be readily applied to ML collections and services in Canadian public libraries. Why? Simply put, the Israeli program recognizes that first-rate library service must be informed by an in-depth cultural and linguistic understanding of the populations served. In the Canadian context, an idea that might be worth exploring is for public libraries, of whatever size, to identify ML populations in their service areas, and then have an existing staff member undergo an Israeli-style training program for each identified ML group. Another approach would be for LIS programs to offer blocks of courses that would be specially tailored to address the needs of individual ML groups, such as the Koreans, Chinese, and Russians. For instance, a Korean library module would include courses in the Korean language, Korean history, and Korean culture and literature, as well projects to design computer user interfaces for Korean-speaking library patrons, explore contemporary reading interests of Koreans, and gain familiarity with Korean-language publishers in North America and abroad. This recommendation is summarized in the IFLA document Multicultural Communities Guidelines for Library Services, which urges that "Library schools should ensure that all courses deal with the issues involved for library staff in an ethnically, linguistically or culturally diverse society" (emphasis added) (IFLA 1998, Section 7.4[a]).

On a more concrete level, public libraries can enter into partnership arrangements with private companies that enable what Henczel and Monester (2002) call "the streamlined incorporation" of ML collections into existing library collections (par. 2). Henczel and Monester are part of a collaboration between CAVAL Collaborative Solutions (CAVAL) and the Foreign Language Bookshop (FLB) that delivers shelf-ready materials in more than 70 non-English languages to many public libraries in Australia and New Zealand at a "fair price" (par. 22). Recognizing that "[e]ach country and culture has a different reading profile" and that "politics, religion, regional economics, and literacy standards" affect library collection development, FLB attempts to select "the titles most attractive to the readers of a local community rather than those titles deemed to be suitable by intellectuals" (par. 13-14). Alternatively, based on the model of the Southern Ontario Multilingual Pool, described by Skrzeszewski (1993), a group of libraries can contribute money to establishing a collection of $\mathrm{ML}$ resources-resources that can then be rotated in blocks through member libraries and be made available through interlibrary loan arrangements (132). Another idea may be to seek grants from funding agencies when demographic trends reveal that a predetermined number of immigrants (e.g., 50) speaking a foreign language has moved into the service area of the public library. For instance, the Everett (Wash.) Public Library, using statistics from the school district and the 2001 Census showing an influx of Vietnamese, Russian, and Arabic speakers into the county, and noting that "the library's Evergreen branch has no foreign language materials and the bookmobile reported unmet demands for children's books in Arabic," applied for a $\$ 34,660$ grant to increase its collections in these languages and to market its services to these linguistic communities (Goffredo 2002, par. 9).

These are worthwhile approaches to the dilemma faced by many public libraries seeking to strengthen their $\mathrm{ML}$ collections. However, it is also important to heed the findings of Berger (2002), who reports on a survey of how 
Danish ethnic minorities use public libraries and their satisfaction levels with library services. With regard to collections and collection development, Berger explains that it is "mainly adults that demand and use materials in their mother tongue" and that these adults "also wish to influence which books and music the libraries purchase" (83). Not only do they prefer titles dealing with topics "related to the cultural context of the immigrants' original countries such as books on cooking, childcare, sex guidance, religion, history, and contemporary politics," they also want materials that "help them maintain and develop their familiarity with the history, culture, and current developments of their native country" (83). Involving immigrant community members in library plans and purchasing decisions of foreign-language materials is therefore something that should not be overlooked, especially because of the relatively few library staff members who have knowledge of foreign languages and cultural issues. This suggestions leads to one area for future research; namely, looking at the extent to which public libraries take steps to involve ML community members in collection development decisions, the ways in which this process works, the advantages and disadvantages of this process, and the outcomes of this process in terms of library use, circulation, and satisfaction levels.

Finally, there is the vexing question of donations and appeals to members of ethnic and immigrant communities for financial help in supporting the development of multilingual collections and services. To be sure, this can often be one way to begin a collection in a specific foreign language. As Skrzeszewski (1997) points out, the Toronto Reference Library increased its collection of Turkish materials through the valiant efforts of one individual staff member who "wrote to community newsletters, sent letters to the Consulate, and asked friends from Turkey and the community to donate books, ... [and] established a partnership between the National Library of Turkey and the Metropolitan [Toronto] Library" (92). The NLC survey indicates that four large library systems partly rely on funding from the ethnic community and donations to increase their ML collections (Multicultural Resources and Services $2002,3,5,10)$. Although these may be appealing methods of collection development, especially when public libraries are faced with tight budgets, the results may be mixed in terms of collection quality; after all, not all donations may be adequate. As well, the message that such reliance on direct financial support from the immigrant community sends may not be entirely positive; after all, shouldn't substantial base funding for ML collection development be built-in to a library's operating budget, and shouldn't that funding be coming from federal, provincial, and municipal coffers? When all is said and done, and given the reality of tight budgets, making decisions about how a library's collections budget will be allocated becomes a matter of prior- itization. Do public library systems need dozens (often hundreds) of copies of the latest English-language bestsellers? Do they need to have numerous subscriptions to English-language glossy magazines with dozens (often hundreds) of pages of advertisements? Although these may seem to be trivial questions, they nonetheless suggest the larger issue that Canadian public libraries face on a daily basis - the degree of their real commitment to making ML collections an integral and central part of their community service, as well as the degree of their commitment to asking difficult questions about how their emphasis on Englishlanguage materials detrimentally affects their ability to provide ML collections.

For instance, we noted above that the Toronto Public Library increased its French and ML materials budget to $\$ 1.5$ million, or $12 \%$ of the budget (Toronto Public Library 2001). However, according to the 1996 statistical profile for the Toronto Census Metropolitan Area (CMA) (the most recently available at the time of the writing of this article), out of a total population of $4,263,755$ in the Toronto CMA, there were 1,578,080 individuals who had first learned a language or languages other than English or French, and still understood that language or languages (Statistics Canada 1996b). In addition, there were 46,065 individuals who first learned and still understand French. If these two figures are added, then $38.1 \%$ of the total population of the Toronto CMA first learned and still understands a language other than English. If figures for the City of Toronto are used, the total population of the City of Toronto is 653,730. The number of people who first learned a language other than English or French and still understand that language is 262,155 . The total number of people who first learned French and still understand it is 10,445 . Therefore, $41.6 \%$ of the total population of the City of Toronto first learned, and still understand, a language other than English.

Of course, other figures could be used as indications of the ML population in the Toronto area; no figures are perfect. Also, the census figures for 2001 will likely reveal a substantial increase in the number of individuals having knowledge of a non-English language because of strong rise in immigration. But the point is this: the figure of $38.1 \%$, which represents that number of individuals who first learned (and still understand) French and other nonEnglish languages in the broad Toronto area, is very far removed from the figure of $12 \%$ that the Toronto Public Library spends on its French and ML collections. It could therefore be argued that the Toronto Public Library has established priorities such that its expenditures on French and ML materials are substantially below the percentage of potential ML clients in its service area who may want to use French and ML materials. This may be a naïve view, but it bears thinking about. 


\section{Conclusion}

As the ML population of Canada increases in the 21st century and as ML populations begin to settle in mid-sized cities and small towns, public libraries should seriously consider making a commitment to view every aspect of library work through the prism of multilingualism, just as LIS schools should restructure the contents of all their courses to ensure that ML issues, in all their myriad applications, become the focus of instruction. Certainly, the ML collections of some Canadian public libraries are, according to the results reported here, underused. But is this because the existing ML collections and services are not adequate, or is it truly because there are not enough ML speakers interested in ML collections or services? No matter the size of a public library, ML collections and services should be viewed as the cornerstone of a library's commitment to forging a sense of inclusiveness and encouraging real intercultural understanding. The package of initiatives proposed by NLC, which includes "the provision of online acquisition tools, cooperative cataloguing, access to evaluated Internet resources in heritage languages [and a] directory of multilingual collections," constitutes a tremendous asset to Canadian public libraries as they move toward expanding their ML collections (Zielinska 2002 , 5). Yet, access to invaluable centralized resources should not lead to an over-reliance on such resources to the detriment of local initiatives that are driven by the immediate and unique needs of an individual immigrant community in a particular geographic location, and that involve immigrant community members in decisions affecting the scope and range of a library's ML collections. Some of the collection development methods identified in the present study (see table 9) can serve as the basis for expanding ML collections and attracting various ML populations to the public library, especially if local foreign language speakers are encouraged to work as full partners with professional library staff in making use of these selection tools and strategies. In addition, public libraries should engage in strenuous lobbying efforts at the federal, provincial, and municipal levels to ensure substantial and stable funding for ML collection development so that the quality and breadth of their ML collections are not dependent on uncertain donations and chancy funding sources that often have the effect of making ML collection development a haphazard affair and that symbolically situate it as an "extra" or "additional" activity. If public libraries succeed in making a strong commitment to professional and inclusive ML collection development based on continuous and stable funding, then they can become, in the words of Aguirre (2001), the kinds of "intellectual spaces" (69) where both young and old immigrants acquire "cultural capital" (86), as well as places where immigrant community members have a full and proudly participatory ownership stake.

\section{Works Cited}

Aerts, Nicole. 2000. Survey of multilingual library services in BC: Final report. Accessed Mar. 11, 2002, www. mcaws.gov.bc.ca/lgd/public_libraries/REPORTS/multi _report.pdf.

Aguirre, JoAnn K. 2001. Passport to promise: Public libraries as intellectual spaces for immigrant students. In Immigrant politics and the public library, ed. Susan Luévano-Molina, 69-88. Westport, Conn.: Greenwood. American Library Directory (54th ed.). 2002. New York: Bowker.

Berger, Ågot. 2002. Recent trends in library services for ethnic minorities-The Danish experience. Library Management 23, no. 1/2: 79-87.

Berry, John W., Uichol Kim, and Pawel Boski. 1988. Psychological acculturation of immigrants. In Crosscultural adaptation: Current approaches, ed. Young Yun Kim and William B. Gudykunst, 62-89. Newbury Park, Calif.: Sage.

Bowker Annual Library and Book Trade Almanac (46th ed.). 2001. New York: Bowker.

Chilana, Rajwant. 2001. Delivering multilingual services in public libraries in British Columbia: A case study of the Fraser Valley Regional Library. PNLA Quarterly 65, no. 3: 18-20.

Chu, Clara M. 2000. See, hear, and speak no evil. Reference and User Services Quarterly 39, no. 3: 255-63.

East, Dennis, and Errol Lam. 1995. In search of multiculturalism in the Library Science curriculum. Journal of Education for Library and Information Science 36, no. 3: 199-216.

Freiband, Susan J. 1992. Multicultural issues and concerns in library education. Journal of Education for Library and Information Science 33, no. 4: 287-95.

Gitner, Fred J. 1998. The New Americans Program. Twenty-one years of successful partnerships serving diverse and changing communities. Reference and User Services Quarterly 38, no. 2: 143-45.

Goffredo, Theresa. 2002. Everett library seeks grant to expand foreign collections. The Daily Herald. Accessed Oct. 30, 2002, www.heraldnet.com/Stories/02/2/28/ 15228188.cfm.

Gollop, Claudia J. 1999. Library and information science education: Preparing librarians for a multicultural society. College andResearch Libraries 60, no. 4: 385-95.

Henczel, Sue, and Annette Monester. 2002. Cultivating non-English collections: A unique partnership that alleviates the pain of librarians in multi-language communities. Paper presented June 15, 2002 at the 2002 ALA Annual Conference in Atlanta, Georgia. Accessed Oct. 30, 2002, www.ala.org/work/international/henczel. html. 
International Federation of Library Associations and Institutions. 1998. Multicultural communities guidelines for library services 2d ed. Accessed Jan. 2, 2002, www.ifla.org/VII/s32/pub/guide-e.htm.

Krauss, Clifford. 2002. Canada courts migrant families to revive a declining heartland. The New York Times. Oct. 2.

Lazinger, Susan S., and Bluma C. Peritz. 1993. Managing multilinguality: Israeli's retraining course for new immigrant librarians. Education for Information 11: 181-88.

Multicultural Resources and Services. National Library of Canada. 2002. Multilingual collections and services (Draft copy dated March 15, 2002). Ottawa, Ontario: National Library of Canada. Permission to cite this nonpublic document provided by Kim Mijin (e-mail to first author on Oct. 29, 2002).

Multilingual Materials Subcommittee. American Library Association. 1990. Guidelines for multilingual materials collection and development and library services. Accessed Jan. 2, 2002, www.ala.org/rusa/stnd_ multiling.html.

Mylopoulos, Chryss. 2000. Tending to the city’s needs, serving newcomer immigrants: The value of community information. MultiCultural Review 9, no. 1: 24-27, 57-59.

Nance-Mitchell, Veronica E. 1996. A multicultural library: Strategies for the twenty-first century. College and Research Libraries 57, no. 5: 404-13.

National Library of Canada. 1994. A world of information: Creating multicultural collections and programs in Canadian public libraries. Accessed February 15, 2002 , www.nlc-bnc.ca/9/6/index.html.

Peterson, Lorna. 1999. The definition of diversity: Two views. A more specific definition. Journal of Library Administration 27, no. 1/2: 17-26.
St. Lifer, Evan, and Corinne Nelson. 1997. Unequal opportunities: Race does matter. Library Journal 122, no. 18: 42-46.

Skrzeszewski, Stan. 1993. The southern Ontario multilingual pool: A model for co-operative library service development. Audiovisual Librarian 19, no. 2: 129-36. - 1997. Library services to Turkish communities in Canada. Resource Sharing and Information Networks 12, no. 2: 89-93.

Statistics Canada. 1996a. Population by home language, 1996 Census. Accessed July 26, 2002, www.statcan.ca/ english/pgdb/People/Population/demo29b.htm.

- 1996b. Statistical profile: Population statistics for Toronto (Census Metropolitan Area, Ontario). Accessed Oct. 31, 2002, http://ceps.statcan.ca/ english/Profil/PlaceSearchForm1.cfm.

Statistics Canada. 2001. Population and Dwelling Counts, for Canada, Provinces and Territories, 2001 and 1996 Censuses. Accessed Oct. 28, 2002, www12.statcan.ca/ english/census01/products/standard/popdwell/TablePR.cfm?T $=1 \& \mathrm{~S}=3 \& \mathrm{O}=\mathrm{A}$.

Toronto Public Library. 2001. Anmual performance measures-Additional information on Canadian and multilingual materials. Accessed Oct. 18, 2002, www.tpl. toronto.on.ca/pdfs/board/01sep24/abo_boa_01sep24_ 09.pdf.

Wertheimer, Leonard. 1991. Multiculturalism under siege: Where are the libraries? Canadian Library Journal 48 (Dec.): 381-82.

Zielinska, Marie F. 2002. National Library of Canada reestablishes multicultural resources and services. Online Newsletter: Library Services to Multicultural Populations 2 (spring): 5 .

\section{Appendix}

\section{Collection Development Survey for Canadian Public Libraries}

[This is a reproduction of the Web-based survey that was used as the research instrument in this article.]

Hello! Thank you for taking the time to fill out this survey about the types of multilingual materials you have in your public library. Your help and time is greatly appreciated.

There are only 10 main categories of questions in this survey, and almost all of them can be answered by using dropdown menus and clickable multiple-choice boxes. The entire survey should take you only about 30 minutes to complete. Rest assured that all your answers will remain completely confidential and anonymous, because this survey does not ask for your name or for the name of your library. Again, we highly appreciate the time that you took to help in this project.

I understand that I am giving my consent to participate in this survey by answering the questions and pressing the SUBMIT button on the last page of this survey.

(Note: Please use the navigation buttons found on the pages to move back and forth, rather than the browser's back and forward buttons. This will allow the survey form to retain your information as move you through it, as well as allow you to go back and change information if you choose to.) [This appeared in red on the screen.] 


\section{Introductory Questions}

1A. The public library where I work can best be described as a (pick one from below):

_ Sole location of a public library (no branches)

- Main library of a library system that has branches

- Branch library of a library system that has 5 or fewer branches

_ Branch library of a library system that has between 6 and 10 branches

_ Branch library of a library system that has more than 10 branches

1B. What is the total population of the service area of the library where you work? (If you said branch in question 1A, enter the population served by your branch.)

2. In what province or territory is your library located? Choose one from below:

- Alberta

- British Columbia

- Manitoba

- New Brunswick

- Newfoundland and Labrador

- Northwest Territories

- Nova Scotia

- Nunavut

- Ontario

- Prince Edward Island

- Quebec

- Saskatchewan

- Yukon

3. Please list the three largest populations of people (linguistic groups) in your service area who have the ability to speak a language other than English or French (in this category, you may include people whose native language is not English/French, language students, foreign students, and other bilingual citizens). Beside each linguistic group, please indicate how many people you think there are who speak this language in your service area.

Largest foreign language population is

Approximate number is

Second largest foreign language population is Approximate number is

Third largest foreign language population is

Approximate number is

4. You will notice that the 3 foreign languages that you selected in Question 3 automatically appear at the top of the answer columns for this question. Now, for each of the items listed in the extreme left-hand column (Adult fiction, Adult nonfiction, etc.), PLEASE INDICATE THE NUMBER OF ITEMS THAT YOUR SPECIFIC LOCATION CURRENTLY OWNS in the designated foreign language at the top of the column. For example, if you work at a branch, the numbers given here should refer only to your branch. If you work at the main (or sole) location, the numbers given here should refer only to the main (or sole) location. The word "All" refers to both adult and children's materials.

4A. All reference books:

4B. Adult fiction books (paperback and hardcover):

4C. Adult nonfiction books (paperback and hardcover): 
4D. Children's books (paperback and hardcovers):

4E. All newspapers:

4F. All magazines:

4G. All entertainment movie videos and DVDs:

4H. All music CDs:

4I. All English-learning materials in this language:

4J. All computer software:

4K. Other-please describe:

5. What are the three biggest constraints that prevent you from having more materials in these three foreign languages?

6. You will notice that the 3 foreign languages that you selected in Question 3 automatically appear at the top of the answer columns for this question. Now, for each of the items listed in the extreme left-hand column (Adult fiction, Adult non-fiction, etc.), PLEASE INDICATE THE NUMBER OF ITEMS THAT YOUR SPECIFIC LOCATION WOULD LIKE TO OWN in the designated foreign language at the top of the column. For example, if you work at a branch, the numbers given here should refer only to your branch. If you work at the main (or sole) location, the numbers given here should refer only to the main (or sole) location. The word "All" refers to both adult and children's materials.

6A. All reference books:

6B. Adult fiction books (paperback and hardcover):

6C. Adult nonfiction books (paperback and hardcover):

6D. Children's books (paperback and hardcover):

6E. All newspapers:

6F. All magazines:

6G. All entertainment movie videos and DVDs:

6H. All music CDs:

6I. All English-learning materials in this language:

6J. All computer software:

7. Is there any other type of material in these 3 foreign languages that you would like to have in your library?

8. This two-part question asks about electronic resources on your library's Web site. For each of the questions, choose one of the four offered choices.

8A. On your Web site, do you have links to foreign language materials (such as newspapers, magazines, government documents, etc.) that may be of interest to speakers of the top three foreign languages spoken in your library's service area?

_ We have many of these ( 5 or more) on our Web site

- We have a few of these (less than 5), but we would like to have more

- We don't have any, but would like to have some

- We don't see a need for such things

8B. Does your library Web site utilize character encodings (e.g., Cyrillic, Chinese, Arabic, etc.) that allow people to read foreign language materials in that foreign language?

- We have many of these ( 5 or more) on our Web site

- We have a few of these (less than 5), but we would like to have more

- We don't have any, but would like to have some

- We don't see a need for such things 
THIS NEXT SET OF QUESTIONS DEALS ONLY WITH PRINTED MATERIAL (BOOKS, NEWSPAPERS, MAGAZINES) IN FOREIGN LANGUAGES.

For these questions, we would like to know how you go about selecting (finding out about) AND then actually buying foreign language print materials. Note that we are making a distinction between selecting and buying. We're only going to ask you about the foreign language that you have the most of in your library.

Place the name of this foreign language here:

9. Choose the answer that best describes your use of each of the methods described in the extreme left-hand column of this question.

9A. Printed catalogs of foreign language publishers:

9B. Web sites of foreign language publishers:

9C. Web sites that review foreign language materials:

9D. Local foreign language specialty bookstores (in your town or city):

9E. Foreign language bookstores that are in another North American city:

9F. Bookstores in the country where this foreign language is spoken:

9G. Web sites of foreign language bookstores anywhere in the world:
I use this method to

ACTUALLY PURCHASE

printed material in this

foreign language

I use this method to FIND OUT about printed material in this foreign language

_ About once a month

_ About 6 or 7 times per year _ About 3 or 4 times per year

_ About once or twice per year

_ Never

_ About once a month

_ About 6 or 7 times per year

_ About 3 or 4 times per year

_ About once or twice per year

_ Never

_ About once a month

_ About 6 or 7 times per year

- About 3 or 7 times per year

_ About once or twice per year

_ Never

_ About once a month

_ About 6 or 7 times per year

_ About 3 or 7 times per year

- About once or twice per year

- Never

_ About once a month

_ About 6 or 7 times per year

_ About 3 or 7 times per year

_ About once or twice per year

_ Never

_ About once a month

— About 6 or 7 times per year

_ About 3 or 7 times per year

_ About once or twice per year

_ Never

_ About once a month

_ About 6 or 7 times per year

_ About 3 or 7 times per year

_ About once or twice per year

_ Never
About once a month

_ About 6 or 7 times per year _ About 3 or 4 times per year

_ About once or twice per year

_ Never

_ About once a month

_ About 6 or 7 times per year

_ About 3 or 4 times per year

- About once or twice per year

- Never

_ About once a month

_ About 6 or 7 times per year

_ About 3 or 4 times per year

_ About once or twice per year

_ Never

_ About once a month

_ About 6 or 7 times per year

_ About 3 or 4 times per year

_ About once or twice per year

_ Never

_ About once a month

_ About 6 or 7 times per year

_ About 3 or 4 times per year

_ About once or twice per year

_ Never 
9H. Library staff who speak this language:

9J. Local people (non-library staff or volunteers) who speak this language:

9K. Approval plans used by my library:

9L. Other (please describe):

9I. Library volunteers who speak this language:
_ About once a month

About 6 or 7 times per year

- About 3 or 7 times per year

_ About once or twice per year

- Never

10. This last set of questions asks about what you are doing to prepare your staff to dro
patrons. For each individual question, check one of the four offered choices.

10A. Do you have any paid staff who work 20 or more hours in your library who speak any of the three foreign languages identified in question 3?

- Yes

- We're working on implementing this within the next year

- We are aware that we need to do this, but right now we don't have the time or money to do it

- There is no need and no plans for us to do this

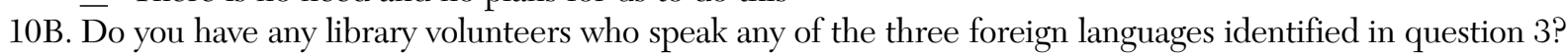

- Yes

- We're working on implementing this within the next year

- We are aware that we need to do this, but right now we don't have the time or money to do it

- There is no need and no plans for us to do this

10C. $\overline{\text { Has }}$ your library put together a collection of staff development resources (videos, pamphlets, etc.) on issues of diver sity and multiculturalism?

- Yes

- We're working on implementing this within the next year

— We are aware that we need to do this, but right now we don't have the time or money to do it

_ There is no need and no plans for us to do this

10D. Does your library provide diversity training sessions (at least 3 in the past year) to staff? Diversity training courses provide instruction in such things as cross-cultural communication and so on.

- Yes

_ We're working on implementing this within the next year

- We are aware that we need to do this, but right now we don't have the time or money to do it

— There is no need and no plans for us to do this 
10E. Has your library conducted a formal needs assessment study about non-English and non-French language speakers in your community?

- Yes

_ We're working on implementing this within the next year

_ We are aware that we need to do this, but right now we don't have the time or money to do it

- There is no need and no plans for us to do this

10F. Has your library conducted a user-survey targeting non-English and non-French speakers in your community?

- Yes

- We're working on implementing this within the next year

_ We are aware that we need to do this, but right now we don't have the time or money to do it

_ There is no need and no plans for us to do this

10G. $\bar{D}$ o you have a mechanism that allows foreign language speakers to make suggestions about how your library can improve service to them?

Yes

_ We're working on implementing this within the next year

_ We are aware that we need to do this, but right now we don't have the time or money to do it

_ There is no need and no plans for us to do this

10H. Has your library developed community outreach partnerships with various non-English and non-French cultural groups to help shape collection development policy in your library?

- Yes

- We're working on implementing this within the next year

- We are aware that we need to do this, but right now we don't have the time or money to do i

_ There is no need and no plans for us to do this.

By pressing the submit button, you will submit your survey and see your results.

\section{LRTS STATEMENT OF OWNERSHIP, MANAGEMENT, AND CIRCULATION}

Library Resources \& Technical Services, Publication No. 311-960, is published quarterly (April, July, October, and January) by the Association for Library Collections and Technical Services, American Library Association, 50 E. Huron St., Chicago, Illinois 60611-2795. Annual subscription price, \$27.50. American Library Association, 50 E. Huron St., Chicago, Illinois 60611-2795, owner; Association for Library Collections and Technical Services, American Library Association, 50 E. Huron St., Chicago, Illinois 60611-2795, publisher; John Budd, University of Missouri, 221M Townsend Hall, Columbia, Missouri 65211, editor. Periodicals postage paid at Chicago, Illinois. Printed in U.S.A. As a nonprofit organization authorized to mail at special rates (DMM Section 424.12 only), the purpose, function, and nonprofit status for federal income tax purposes have not changed during the preceding twelve months.

\section{EXTENT AND NATURE OF CIRCULATION}

("Average" figures denote the average number of copies printed each issue during the preceding twelve months; "actual" figures denote actual number of copies of single issue published nearest to filing date: April 2002). Total number of copies printed: average, 6,520; actual 6,780. Sales through dealers and carriers, street vendors, and counter sales: none. Paid or requested mail subscriptions: average, 6,032; actual, 6,214. Free distribution (total): average, 46; actual, 41. Total distribution: average, 6,078; actual 6,255. Office use, leftover, unaccounted, spoiled after printing: average, 442; actual, 525. Total: average, 6,520; actual, 6,780. Percentage paid: average, 99.24; actual, 99.35. 